от духа подлинника. В лучших переводах Маршака всегда есть точность портрета. Если речь идет о народной поэзии, - например, латышской, - мы живо ощущаем крепкую, здравомыслящую, добродушную и в то же время строгую музу латышских крестьянских песен; если речь идет о переводах лирики Шекспира и Бернса, мы чувствуем, так же как в стихах Беранже, переведенных Курочкиным, все обаяние личности каждого из этих поэтов. Со всей полнотой доходит до нас присущая сонетам Шекспира глубина мысли, изящной, тонкой и притом смелой, независимой и правдивой. В стихах Бернса прежде всего пленяет образ самого автора свободолюбивого, неподкупного человека, гордого сознанием, что все лучшее дается людям бескорыстно, что честность, как и простые человеческие радости, нельзя купить ни за какие деньги.

$$
* * *
$$

1. И.С. Тургенев. Сочинения, М - Л., Гослитиздат, 1963, т. ХІІ.

2. Маршак С.Я. Собрание сочинений в восьми томах. Т. 2. Том 2. Изд. Художественная литература». M., 1968.

3. Маршак С.Я. Собрание сочинений в восьми томах. Т. 4. Том 4. Изд. «Художественная литература». М., 1968.

\title{
Гейдарова Э.А. \\ Метафорические номинации в лексике трудовой деятельности (на материале русского островного говора Азербайджана)
}

Бакинский государственный университет (Азербайджан, Баку)

doi 10.18411/gq-31-07-2021-22

\section{Аннотация}

Рассматриваются метафорические номинации в лексике, связанной с трудовой деятельностью носителей русского островного говора Азербайджана. В результате проведенного исследования выявлено 26 метафор. В рамках четырех лексикотематических групп («Земледелие и скотоводство», «Пчеловодство и садоводство», «Рыбный промысел», «Ткачество») представлены биоморфные (11), предметные (9), социальные (4) и геоморфные метафоры. Исследование показало, что для создания метафор активнее всего используется биоморфная сфера. Источником метафоризации выступает не только исконная, но и заимствованная лексика.

Ключевые слова: русский островной говор, лексико-тематические группы слов, метафорические номинации, лексика трудовой деятельности, земледелие, скотоводство, пчеловодство, садоводство, рыбный промысел, ткачество.

\section{Abstract}

Considers metaphorical nominations in the vocabulary associated with the labor activity of native speakers of the Russian island dialect of Azerbaijan. As a result of the research 26 metaphors were identified. Within the framework of four lexical-thematic groups («Agriculture and cattle breeding», «Beekeeping and gardening», «Fishing industry», «Weaving») biomorphic (11), subject (9), social (4) and geomorphic metaphors are presented. The research has shown that the biomorphic area is most actively used to create metaphors. The source of metaphorization is not only native, but also borrowed vocabulary.

Keywords: the Russian insular dialect, lexico-thematic word groups, metaphorical nominations, vocabulary of labor activity, agriculture, cattle breeding, beekeeping, gardening, fishing industry, weaving.

Русский островной говор Азербайджана, «сформировавшийся из разных диалектов русского языка, в иноязычном окружении приобрел ряд общих черт, 
позволяющих представить его как одну из групп южновеликорусского наречия» [5, с. 6]. Он относится к числу нивелирующихся, оторван от метрополии и с самого начала находится в иноязычном окружении.

Лексика русского островного говора Азербайджана, распределенная по тематическим группам, охватывает все сферы жизни носителей говора. Однако наибольшее количество слов вошло в группу, связанную с трудовой деятельностью. Ведь «в лексике любого языка находит отражение род той деятельности, которой издревле занимался народ - носитель этого языка» [7, с. 78].

Задачей настоящего исследования было выявление метафорических номинаций в рамках четырех лексико-тематических групп - «Земледелие и скотоводство», «Пчеловодство и садоводство», «Ткачество», «Рыбный промысел». Материалом исследования послужил «Лексикон русского островного говора Азербайджана».

Широко представленная земледельческая терминология включает 234 слова. К лексике, связанной со скотоводством, относится 151 слово, а к орудиям труда - 109. Одним из родов деятельности диалектоносителей является пчеловодство, поэтому в исследуемом говоре употребляется 30 слов, относящихся к этой сфере. Женщины занимаются ткачеством, на что указывают 35 слов. «В языке поселенцев, осевших недалеко от берегов Каспийского моря, появляется новая терминология, связанная уже с рыбным промыслом (37 слов)» [2, с. 74].

В целом, лексика, связанная с трудовой деятельностью, включает в свой состав 596 слов.

Исследуемый русский островной говор Азербайджана представляет интерес и в связи с тем, что иноязычное окружение, тесные дружеские межкультурные и экономические связи способствовали проникновению значительного пласта заимствований из языка местного населения в повседневное активное общение русских переселенцев.

Следовательно, «в лексике говора отражаются не только исконные, национальные духовные ценности, выработанные русскими на протяжении столетий» [1, с. 174], но и приобретённые инонациональные особенности духовной и материальной культуры, заимствованные у иноязычных соседей, что является одной из причин возникновения лексико-семантического своеобразия речи диалектоносителей, проявляясь, в частности, в метафорических переносах.

\section{Земледелие и скотоводство}

В группе выявлены биоморфные метафоры, которые представлены антропоморфными и зооморфными номинациями. К антропоморфным метафорам относятся следующие примеры:

Барма́ки "вилы для веяния": Kaдbl в 'е́ŭym, нъб’ира́йуm' бърмакам'и. Энтъ в и́льь так'úu. [3, с. 121] Метафорический перенос образовался в результате сходства металлических зубьев вил с пальцами человека (от азерб. barmaq-naлеu).

Глазо́к "почка картофеля". На поверхности клубня проросшего картофеля бывают углубления, в которых располагаются почки. Внешне они схожи с глазницей и глазным яблоком, что и послужило основой метафорического переноса. Учитывая то, что почки у начинающего прорастать картофеля небольшие, номинация возникла в русском языке от уменьшительной формы глазо́к. Данная метафора получила широкое распространение в русском языке, она активно употребляется и носителями островного говора.

Косма́тка "сорняк". Название возникло из-за сходства сорняка с ко́смами, т.е. с взлохмаченными прядями волос.

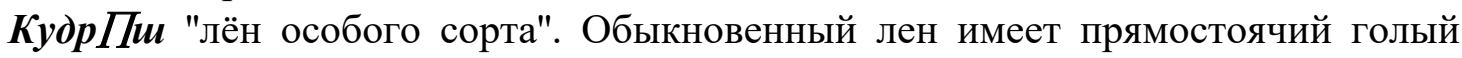
стебель. Однако у некоторых видов стебель ветвится, что вызывает ассоциацию с вьющимися волосами, кудрями. Достаточно вспомнить строки стихотворения поэтапесенника Александра Шаганова «Выйду ночью в поле с конем». 
Будет добрым год-хлебород.

Было всяко, всяко пройдёт.

Пой, златая рожь, пой, кудрявый лен... [8]

Зооморфные метафоры представлены такими примерами, как:

Хоботки́ "шелуха, остающаяся после очистки зерна". Одно из значений слова хобото́к (мн.ч. хоботки) в русском языке - «вытянутый в трубку рот некоторых членистоногих, служащий для сосания, ощупывания, прокалывания». [6] Метафорический перенос основан на внешнем сходстве шелухи зерна с хоботком насекомых.

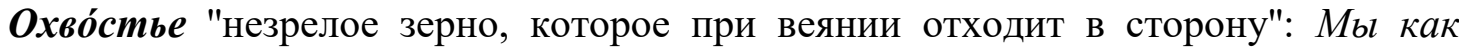
в е́йьм, в адну́ сто́ръну ав 'е́ршйь - Гть по́лнъйь з'ирно́, а в друүу́йу - ахво́с 'm 'üь. [4, с. 292] Носители русского островного говора являются, в основном, сельскими жителями, активно занимающимися и животноводством. Метафорическая номинация, возможно, возникла в результате сходства процесса обрубания (обрезания) хвостов у ягнят некоторых пород с незрелым зерном, которое отсеивается.

В результате исследования выявлены примеры геоморфной метафоры.

Брод "след, протоптанный по траве, разделяющий участки покоса, межа": Бро́д

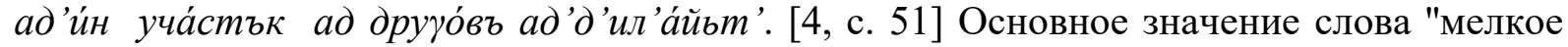
место реки и т.П., которое можно перейти или переехать". Основу переноса составило сходство перехода в реке или озере с узкой тропинкой, протоптанной в траве и обозначающей границы земельных участков.

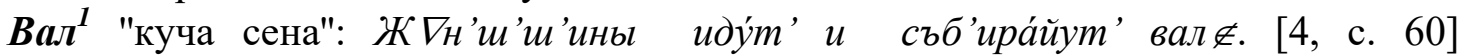
Номинация возникла из-за ассоциаций собранных куч сена с земляными насыпями.

В говоре активно представлена предметная метафора. Учитывая то, что сходство четко обозначено, и этимология переноса не вызывает проблем, нет необходимости подробно раскрывать примеры.

Руба́шка "шелуха от колосьев пшеницы".

Волна́ "шерсть овец".

Шnи́лька "железные наконечники на деревянных ступах сипара": Шn'и́л'к’u очиш'ш'áŭym' чалт $\notin к$ ат шънапу́л'u. [4, с. 585]

Крюк "приспособление, предназначенное для скашивания зерновых культур; вид косы": C'арпо́м жа́л'u, кас'и́л'u кр’ука́м'u. [4, с. 217]

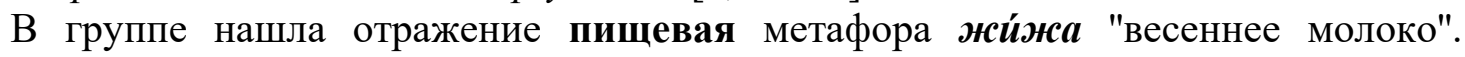
Причиной переноса послужило жидкое, нежирное молоко, вызвавшее ассоциацию с жижей. Основное значение данного слова в говоре - "вода, жидкость". Ср.: Baнá ўc'é

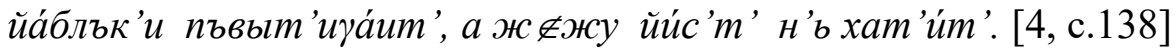

Лексика, связанная с земледелием, включает в свой состав следующие метафоры: биоморфные - 6, которые представлены антропоморфными (4) и зооморфными (2) номинациями, предметные - 4, геоморфные - 2, пищевая - 1 .

\section{Пчеловодство и садоводство}

В группе выделяются социальные метафоры.

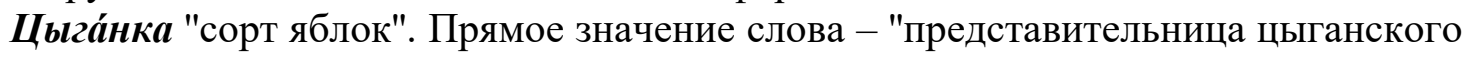
народа", т.е. основанием для метафорического переноса явился этноним. Номинация возникла в русском языке в XVII веке на основе ассоциаций наливного яблока с образом цыганки. Сходство основано на том, что желтоватая кожица яблока, залитая буро-красным румянцем и покрытая светлыми крапинками, напоминает одежду цыганки, традиционно имеющую яркие цветочные узоры. Метафорическая номинация входит в словарь носителей русского островного говора Азербайджана.

Чи́стиильщики "название молодых пчёл, которые чистят соты": Пчо́лъм'и чи́с'm'ил'ш'ш'икъм'и чи́с'm’ьциъ со́ты в у́л'икъх. [4, с. 471] Метафора возникла по названию рода деятельности. 
Предметная метафора нашла свое отражение в двух номинациях.

Корзи́ночка "волосинка на лапке пчелы": Ф карзи́нъчку пчила́ съб’ирáum' nыл'иý. [4, с. 207] Пример наглядно демонстрирует результат образного мышления диалектоносителей. Пчела собирает пыльцу ворсинками, покрывающими ее тело. Затем она лапками снимает пыльцу и скатывает в комочек, который переносит на задних ножках. По всей вероятности, ворсинки пчелы, с помощью которых насекомое собирает пыльцу, вызвали ассоциацию с корзинкой (уменьш.-ласкат. корзи́ночка), так как в деревнях этот предмет активно используют для сбора овощей, фруктов и т.д.

Мешо́чек "брюшко пчелы". Метафорический перенос основан на внешнем сходстве брюшка пчелы с маленьким мешочком.

Всего в группе выявлены 2 социальные и 2 предметные метафоры.

Ткачество

В группе отмечена предметная метафора стру́ны "нитки": Стру́ны м'ин'е́ кра́сныйь нужн $\notin$. [4, с. 403] Номинация возникла на сходстве натянутых при прядении ниток со струнами.

Антропоморфная метафора представлена несколькими примерами.

Кива́лка "педаль прядильного станка": Пълама́лъс' к’ива́лкъ нъ стани́. [4, с. 193] Перенос осуществлен на основе сходства движения педали станка вверх и вниз с киванием - наклонным движением головой в знак приветствия или одобрения.

Кудря́вка "пряжа": Снтъ стал'е́шн'ик ис кудр'а́фк'и. [4, с. 218] Как известно, пряжа - это нить, состоящая из нескольких волокон, расположенных рядом друг с другом и затем скрученных вместе. Метафорическая номинация возникла на основе ассоциаций пряжи с вьющимися волосами, кудрями.

В группе отмечена социальная метафора плясуно́к "веретено". Перенос вызван сходством крутящегося веретена с пляшущим человеком. Модель образована от слова плясу́н "тот, кто пляшет (любит и умеет плясать)". В номинации употребляется уменьш. форма.

Всего в группе выявлены 4 метафоры - 2 антропоморфные, 1 социальная и 1 предметная.

\section{Рыбный промысел}

Для добычи рыбы используются сети разного размера и формы, что вызвало появление многочисленных метафорических номинаций. Например, зооморфная метафора мо́рда "сеть для ловли рыбы": У м’ин'á мо́рдъ пьрвала́с'. [4, с. 250] Данная сеть известна с глубокой древности и представляет собой два конуса, сплетенных из прутьев красной ивы и вставленных один в другой. Сбоку эта ловушка для рыб напоминает голову животного, за что и получила название мо́pда.

Социальная метафора представлена примером мал єuка "рыболовная сеть в виде зонта": Рыба́к забро́с'ил мал єшку в мо́р'b. [4, с. 238] На территории материнских диалектов эта сеть имеет название зо́нтик. Однако в исследуемом говоре отмечена иная метафорическая номинация. Основное значение слова мал єика - "уменьш.-ласкат. обращение к малышу". Диалектоносители используют его для актуализации небольшого размера сети, вкладывая при этом свое личное отношение к предмету рыбной ловли.

Антропоморфная метафора представлена примером yсáч "пескарь": Усачи́ во́d’ьuцъ в на́шых p'éкъx. [4, с. 433] В разговорном языке усачом называют человека с большими усами. Однако слово послужило также основой для названия речной рыбы семейства карповых.

В следующем примере отражается номинация, имеющая отношение к анатомии, как человека, так и животного. Поэтому ее можно отнести к биоморфной метафоре, не конкретизируя вид переноса, т.к. неизвестно, антропоморфная или зооморфная метафора послужила основой для данной формы. 
Жи́лка "вид толстой рыболовной лески": Жєлкъй, бл'о́скъй, нак'úткъй ра́знуйу pb́бу ло́в 'am'. [4, с. 139] Название образовано от уменьш. формы к жи́ла "сухожилие".

Предметная метафора нашла свое отражение в двух номинациях.

Блёстка "вид рыболовной лески": К съмало́фк'b бл'о́ск'u н'u на́dъ: ана́ $u$ c'ém', $u$ ýdъчкъ. [4, с. 44] Под блёсткой обычно понимается небольшая блестящая пластинка, употребляемая для украшения, а также искорка света, отражающаяся на какой-либо поверхности. Учитывая то, что данный вид рыболовной лески блестит на солнце, появилась ассоциация с блёстками.

Маха́лка "хвостовая часть рыбы". Основу метафорического переноса составило:

1) внешнее сходство с метлой (ср. машет метлой);

2) сходство с предметом, который служит для обмахивания.

В ходе проведенного исследования было выявлено 6 метафорических номинаций: предметные -2 , биоморфные -1 , антропоморфные -1 , зооморфные -1 , социальные - 1 .

Таким образом, в рамках четырех лексико-тематических групп представлены биоморфные (11), предметные (9), социальные (4) и геоморфные (2) метафоры. Исследование показало, что для создания метафор активнее всего используется биоморфная сфера. Источником метафоризации выступает не только исконная, но и заимствованная лексика.

$* * *$

1. Гейдарова Э.А. Языковой портрет русского островного говора Азербайджана. Москва: Университетская книга, 2017, 303 с.

2. Гейдарова Э.А. Русская языковая картина мира (на материале русского островного говора Азербайджана). // Вопросы когнитивной лингвистики. 2016, № 4, с. 68-77.

3. Гейдарова Э.А. Лексическая система русского островного говора Азербайджана. Баку: AVROPA, 2015, $178 \mathrm{c.}$

4. Гулиева Л.Г., Гейдарова Э.А. Лексикон русского островного говора Азербайджана. Баку: Авропа, 2014, 498 c.

5. Гулиева Л.Г., Мамедбейли Ф.АГ., Гейдарова Э.А., Керимова Г.О. Словарь русского островного говора Азербайджана. Баку: Tehsil, 2006, 641 с.

6. Ефремова Т.Ф. Новый словарь русского языка. Толково-словообразователь ᄀный. М.: Русский язык, 2000. [Электронный ресурс] URL: https://www.efremova.info/word/guzka.html\#.YAh1Y3YzbIU

7. Сабитова 3.К. Лингвокультурология. М.: Флинта, Наука, 2015, 528 с.

8. Шаганов А.А. «Выйду ночью в поле с конем».// [Электронный pecypc] URL: https://drinkingsongs.ru/slova-pesen/vyjdu-nochyu-v-pole-s-konyom.html 